\title{
SYTUACJA PRAWNA PRACOWNIKA POWRACAJĄCEGO DO PRACY PO WYKORZYSTANIU URLOPÓW ZWIAZZANYCH Z RODZICIELSTWEM - UWAGI DE LEGE FERENDA
}

\author{
Abstract \\ Legal situation of an employee returning to work after use of parental \\ leave - postulates de lege ferenda
}

Labour law provisions meet the expectations of employees who are also parents and enable them to connect a professional work with parental responsibilities. There is always a guarantee of employment granted by employer to the employee after returning from parental leave and that is because of an articles $183^{2}$ and $186^{4}$ of the Polish Labour Code which protect these employees. The protection is also granted to the employee who is entitled to a parental leave but he or she decides to lower his or her workload what is considered as alternative form of parental leave. If employee returns to work for his or her employment in a previously given post, equivalent post or other in accordance with his or her qualifications it should not adversely affect his or her financial situation. These labour law provision guarantees a salary which he or she would receive if he or she would not use a parental leave. These provisions do not forbid an employer to provide notice of changing termination or definitive termination, but as long as there is a possibility of mandate other work to the returning employee, definitive termination is not justified. The subject of analysis are valid labour law provisions in order to verify if assumption of the legislator about stabilization of employment for employees who are also parents returning to work after parental leave is fully implemented in practice. In conclusion, in relation with expanding the range of application article 186 (8) $\$ 2$ of the Polish Labour Code by jurisprudence, the position of an employee returning to work after using parental leave has been weakened.

Słowa kluczowe: urlop rodzicielski, dopuszczenie do pracy, ochrona związana z rodzicielstwem, urlop wychowawczy

Key words: parental leave, admission to work, protection associated with parenthood, childcare leave 


\section{Wprowadzenie}

Zmieniające się przepisy Kodeksu pracy, które wychodzą naprzeciw oczekiwaniom pracowników rodziców, umożliwiając im łączenie pracy zawodowej z obowiązkami rodzicielskimi, należy ocenić pozytywnie i z dużą aprobatą. Szczególnie mowa tu o art. $182^{1} \mathrm{~d}$ kp, który został dodany Ustawą z dnia 24 lipca 2015 r. i obowiązuje od 2 stycznia 2016 r., pozwalając pracownikowi na łączenie pracy u tego samego pracodawcy z urlopem rodzicielskim. Podobnie zresztą jak wszelkie regulacje, które po narodzinach dziecka wydłużają - wedle woli rodzica (opiekuna) - czas opieki nad dzieckiem. Myślę w tym miejscu o decyzyjności pozostawionej pracownikom, którzy jedynie poza narzuconym przez ustawodawcę 14-tygodniowym okresem obowiązkowego urlopu macierzyńskiego mogą zdecydować, kiedy i na jak długo pozostaną w domu z dzieckiem, który z rodziców lub innych członków najbliższej rodziny będzie taką opiekę sprawować oraz czy chcą korzystać z możliwości łączenia pracy i opieki nad dzieckiem w trakcie urlopu o charakterze rodzicielskim. Chociaż w przypadku wydłużonych urlopów związanych z rodzicielstwem można spotkać się z opiniami, że ustawodawca, dbając w ten sposób właśnie o politykę prorodzinną, całkowicie zapomina o sytuacji, w jakiej musi odnaleźć się pracownik na rynku pracy powracający po przerwie związanej z wykorzystaniem tychże urlopów oraz o pracodawcy zmuszonym ponosić te obciążenia ${ }^{1}$. Czas takiej przerwy może być bardzo różny, ale niewątpliwie każda z takich przerw, jak długa by była, wpływa na zdolność ponownego „zaistnienia” przez takiego pracownika w środowisku pracy. Poza tym ustawodawca założył, iż dla pracownika rodzica powracającego do pracy istnieje zawsze gwarancja zatrudnienia dawana mu przez zatrudniającego go pracodawcę. Dzieje się tak z uwagi na brzmienie art. $183^{2} \mathrm{kp}$, oraz art. 186 (4) kp, które w szczególny sposób chronią zatrudnienie pracowników rodziców (opiekunów) powracających do pracy. Ochrona dawana jest również pracownikowi, który będąc uprawnionym do urlopu wychowawczego, decyduje się na obniżenie wymiaru czasu pracy, co z kolei określa się jako alternatywną formę urlopu wychowawczego ${ }^{2}$.

W niniejszym opracowaniu dokonana zostanie analiza sytuacji prawnej takiego pracownika rodzica (opiekuna), który wykorzystując wyłącznie urlopy rodzicielskie, zamierza, po dłuższej przerwie, powrócić do pracy. Jak w przepisach prawa pracy ukształtowana została sytuacja takiego pracownika? Z jakich uprawnień może skorzystać i przed jakimi zagrożeniami pozostaje chroniony? Pracownik najczęściej bezpośrednio po wykorzystaniu urlopu macierzyńskiego (ale również i urlopu rodzicielskiego) występuje do pracodawcy z wnioskiem ( $w$ trybie art. $163 \$ 3 \mathrm{kp}$ ) o udzielenie urlopu wypoczynkowego,

${ }^{1}$ M. Latos-Miłkowska, Przemiany stosunku pracy zwiąane z rodzicielstwem, w: Współczesne problemy prawa pracy i ubezpieczeń społecznych, L. Florek, Ł. Pisarczyk (red.), XVIII Zjazd Katedr i Zakładów Prawa Pracy i Ubezpieczeń Społecznych, Warszawa, 26-28 maja 2011, s. 221 i n.

2 R. Sadlik, Wypowiedzenie umowy pracownikowi z obniżonym wymiarem czasu pracy, Służba Pracownicza 2013, 7, s. 20 i n. 
co naturalnie wydłuża czas sprawowania osobistej opieki nad dzieckiem i jest okresem, w którym pracownik taki podlega dalszej ochronie. Ale czy przepisy prawa pracy tworzą wystarczającą ochronę dla tej grupy zatrudnionych? Czy w świetle obowiązujących przepisów Kodeksu pracy założenie ustawodawcy o stabilizacji zatrudnienia jest w pełni realizowane? Przedmiotem analizy nie zostali objęci natomiast tacy pracownicy, którzy łączą rolę rodzica (opiekuna) z pracą zawodową i w trakcie urlopów rodzicielskich wykonują pracę w zakresie dopuszczalnym przez przepisy Kodeksu pracy ${ }^{3}$.

\section{Obowiązek dopuszczenia do pracy po zakończeniu urlopów związanych z rodzicielstwem}

Pracownik powracający do pracy po wykorzystaniu urlopów związanych z rodzicielstwem korzysta $\mathrm{z}$ uprawnienia wynikającego z art. $183^{2} \mathrm{kp}$ lub z art. 186 (4) kp, które to w założeniu mają charakter gwarancyjny dla pracownika. W skazane przepisy znajdą zastosowanie zarówno do urlopu macierzyńskiego, urlopu na warunkach urlopu macierzyńskiego, jak i do urlopu rodzicielskiego oraz ojcowskiego. Na gruncie obowiązujących regulacji nie ma natomiast pewności, czy przepisy te znajdują zastosowanie także do zakończenia części urlopu związanego z rodzicielstwem, czy tylko do zakończenia całego urlopu. De lege ferenda należałoby zatem wskazać na konieczność wyraźnego dookreślenia przez ustawodawcę, iż obowiązek dopuszczenia pracownika do pracy istnieje po stronie pracodawcy w przypadku każdego, nawet częściowego, powrotu pracownika do pracy. Uprawnienie pracownika jest w tym przypadku formułowane przez ustawodawcę przy uwzględnieniu rodzaju stanowiska pracy oraz wysokości wynagrodzenia. W przypadku rodzaju stanowiska pracy przepisy Kodeksu pracy pozwalają na daleko idącą elastyczność. Po pierwsze, pracodawca powinien umożliwić pracownikowi podjęcie pracy na dotychczasowym stanowisku, a jeżeli nie jest to możliwe - zaproponować pracę na stanowisku równorzędnym z zajmowanym przed rozpoczęciem urlopu lub pracę na innym stanowisku odpowiadającym kwalifikacjom zawodowym pracownika. Elastyczność rozwiązań, które pracodawca może zaproponować pracownikowi powracającemu z urlopu związanego $z$ rodzicielstwem, dyktowana jest przede wszystkim stosunkowo długim czasem trwania niektórych z tych urlopów oraz zmiennością sytuacji na rynku pracy ${ }^{4}$. Pracodawca może zaproponować pracownikowi zatrudnienie na dotychczasowym stanowisku wyłącznie wówczas, gdy stanowisko pracy istnieje. Jeżeli więc na miejscu pracownika zatrudniono inną osobę, to pracodawca nie będzie mógł zaproponować pracownikowi powracającemu innych możliwości. Taka interpretacja dostatecznie chroni prawo pracownika rodzica

${ }^{3}$ Więcej na temat łączenia pracy zawodowej z opieką nad dzieckiem zob. U. Torbus, Zmiany w zakresie uprawnień rodzicielskich ułatwiających łączenie obowiązków zawodowych $z$ opieką nad dzieckiem, w: Uprawnienia pracowników związane z rodzicielstwem $w$ świetle przepisów prawa pracy $i$ ubezpieczeń społecznych, J. Czerniak-Swędzioł (red.), Warszawa 2016, s. 199 i n.

${ }^{4}$ M. Włodarczyk, Komentarz do art. $183^{2}$ kp, w: Kodeks pracy. Komentarz, K.W. Baran (red.), Warszawa 2015, s.1140. 
(opiekuna) do zajmowania dotychczasowego miejsca pracy. Takie rozwiązanie może przy tym powodować, że status pracownika zostanie ukształtowany mniej korzystnie, ale celem nadrzędnym ustawodawcy było i jest zachowanie zatrudnienia w ogóle. Jeżeli natomiast pracodawca będzie posiadał alternatywne możliwości zatrudnienia dla pracownika powracającego do pracy, to zastosowanie względem niego wypowiedzenia definitywnego będzie całkowicie nieuzasadnione. Celem omawianej regulacji jest zapewnienie zatrudnienia pracownikowi rodzicowi (opiekunowi) powracającemu do pracy i nie chodzi w niej wyłącznie o to, aby pracownik został fizycznie dopuszczony do pracy $^{5}$, a następnie z niej zwolniony, ale o to, aby poprzez dopuszczenie do pracy pracownik miał zapewnioną pracę i mógł się w niej utrzymać.

Niektórzy przedstawiciele doktryny ${ }^{6}$ uznają za zasadne twierdzenie, że pracodawca, zapewniając pracę pracownikowi powracającemu do pracy, po wykorzystaniu urlopów związanych $\mathrm{z}$ rodzicielstwem, dokonuje jednostronnej zmiany treści umowy o pracę bez wypowiedzenia zmieniającego ${ }^{7}$. Inni wskazują, że przewidziana w przepisie zmiana zatrudnienia dokonuje się na drodze polecenia pracodawcy, któremu pracownik ma obowiązek się podporządkować i przystąpić do wykonywania pracy ${ }^{8}$. Pracownik może jednak zakwestionować treść takiego polecenia, zarzucając mu nieprawidłowe zakwalifikowanie danego stanowiska jako równorzędnego z zajmowanym przed rozpoczęciem urlopu albo podważając zgodność kwalifikacji wymaganych do wykonywania pracy na innym przydzielonym mu stanowisku z kwalifikacjami, które posiada ${ }^{9}$. Zdaniem M. Włodarczyka, mając na względzie ochronę interesu pracownika, należy uznać, że w przepisie chodzi o kwalifikacje wskazane w umowie o pracę lub do których nabycia pracodawca się przyczynil, a nie o wszelkie kwalifikacje zawodowe, które pracownik posiada. W literaturze przedmiotu A. Sobczyk ${ }^{10}$ proponuje $\mathrm{z}$ kolei wykładnię alternatywną omawianego przepisu, zgodnie z którą jeżeli umowa o pracę nie określa stanowiska pracy, a jedynie rodzaj pracy, to wówczas zastosowanie znajdzie wypowiedzenie zmieniające. Analizowany przepis bez wątpienia gwarantuje stabilizację zatrudnienia, ale należy zauważyć, że dzieje się tak przy jednoczesnym osłabieniu sytuacji prawnej pracownika, który - zdaniem A. Sobczyka ${ }^{11}$ - nie może odmówić podjęcia zatrudnienia na nieuzgodnionym z nim stanowisku pracy. Pracownik otrzymujący od pracodawcy, po powrocie $z$ urlopu o charakterze rodzicielskim, propozycję zatrudnienia na nowym stanowisku pracy, którym nie jest zainteresowany, może jedynie wypowiedzieć umowę o pracę. Innej możliwości rezygnacji z zaproponowanych przez pracodawcę zmian w zatrudnieniu nie przewidziano w ustawie. Pracownik może, rzecz jasna, zakwestionować decyzję pracodawcy o powierzeniu pracy na innym stanowisku pod kątem nierównego

\footnotetext{
${ }^{5}$ Por. uzasadnienie Uchwały SN z 30.12.1985 r., III PZP 50/85, OSNCP 1986, nr 7-8, poz. 118.

${ }^{6} \mathrm{M}$. Wujczyk, Wypowiedzenie warunków pracy lub płacy w umownym stosunku pracy, Warszawa 2015.

7 Zob. Wyrok SN z 1.10.1984 r., I PRN 129/84, OSNCP 1985, nr 7, poz. 93.

${ }^{8}$ M. Włodarczyk, Komentarz do art. $183^{2}$ kp..., s. 1141.

9 Tamże.

10 A. Sobczyk (red.), Kodeks pracy. Komentarz, wyd. 2, Warszawa 2015, s. 776.

11 Tamże, s. 775.
} 
traktowania oraz domagać się przywrócenia do pracy na poprzednio zajmowanym stanowisku.

Niezależnie jednak od tego, czy pracownik powrócił do pracy na swoje dotychczasowe stanowisko, na stanowisko równorzędne czy też inne zgodne z jego kwalifikacjami, nie powinno to wpłynąć niekorzystnie na jego sytuację finansową. Przepis gwarantuje mu bowiem wynagrodzenie, jakie otrzymywałby, gdyby nie korzystał z urlopu. To oznacza, że objęta gwarancją nie jest nominalna kwota płacy pracownika sprzed urlopu, lecz kwota, która za pracę na danym stanowisku by mu przysługiwała, gdyby nie wystąpiła przerwa urlopowa $^{12}$. Chodzi zatem o uwzględnienie ewentualnych podwyżek, ale i zmian na niekorzyść pracownika, czego polski ustawodawca nie wyeliminował ${ }^{13}$. Sąd Najwyższy w jednym ze swoich rozstrzygnięć wprost wskazał, że podstawą określenia wysokości wynagrodzenia pracownika powracającego do pracy po urlopie wychowawczym nie jest wynagrodzenie pobierane przez niego przed urlopem, lecz wynagrodzenie przysługujące w dniu podjęcia pracy na stanowisku, które zajmował przed urlopem ${ }^{14}$.

W świetle powyższych rozważań należy zauważyć, że sytuacja prawna pracownika powracającego do pracy po wykorzystaniu urlopów związanych z rodzicielstwem nie może być jednak bezwzględnie lepsza tylko dlatego, że jest on pracownikiem rodzicem (opiekunem) wracającym do pracy po urlopie o charakterze rodzicielskim ${ }^{15}$. Wówczas pracodawca powinien dokonać weryfikacji merytorycznej pracowników, tak aby nie doszło ani do dyskryminacji, ani do uprzywilejowania, i zatrudnić lepszego. Weryfikacja decyzji pracodawcy pod kątem nierównego traktowania (dyskryminacji) dotyczy rzecz jasna również pracownika rodzica, który w ten właśnie sposób może z kolei zakwestionować decyzję o powierzeniu mu innej pracy. Podkreślenia wymaga również to, że analizowane przepisy nie zabraniają pracodawcy dokonania wypowiedzenia zmieniającego lub wypowiedzenia definitywnego powracającemu pracownikowi. Z tym że tak długo, jak istnieje po stronie pracodawcy możliwość powierzenia powracającemu pracownikowi innej pracy, tak długo wypowiedzenie definitywne nie będzie uzasadnione. Wówczas pracownikowi przysługuje roszczenie o dopuszczenie do pracy na poprzednio zajmowanym stanowisku, a to właśnie $\mathrm{z}$ uwagi na gwarancje wynikające $\mathrm{z}$ ustawy ${ }^{16}$.

${ }_{12}$ M. Włodarczyk, Komentarz do art. $183^{2}$ kp..., s. 1141.

${ }_{13}$ A. Sobczyk (red.), Kodeks pracy..., s. 776

${ }_{14}$ Wyrok SN z dnia 29.01.2008 r. sygn. akt II PK 143/07.

15 A. Sobczyk (red.), Kodeks pracy..., s. 775.

16 Tamże, s. 777. 


\section{Ochrona dla pracowników rodziców z obniżonym wymiarem czasu pracy}

Pracownicy uprawnieni do urlopu wychowawczego po zakończeniu urlopów związanych z rodzicielstwem mogą łączyć dalsze sprawowanie opieki nad dzieckiem z pracą zawodową. W myśl bowiem art. 186 (7) kp pracownik może złożyć pracodawcy pisemny wniosek - na 21 dni przed rozpoczęciem wykonywania pracy ${ }^{17}$ - o obniżenie wymiaru czasu pracy nie więcej niż do połowy wymiaru pełnego etatu, a pracodawca pozostaje związany takim wnioskiem. Przepis wymaga, aby wniosek został przez pracodawcę uwzględniony, choć mogą zaistnieć też takie sytuacje, w których odmowa pracodawcy będzie w pełni uzasadniona, o czym więcej w dalszej części. Pracownik korzystający z obniżonego wymiaru czasu pracy nie korzysta $\mathrm{z}$ ochrony przed wypowiedzeniem, o której mowa jest w art. $186^{8} \$ 1$ pkt $1 \mathrm{kp}$, gdyż nie przebywa on na urlopie wychowawczym. Do stycznia 2016 r. zakres ochrony pracownika korzystającego z urlopu wypoczynkowego regulowany był poprzez art. $186^{1} \mathrm{kp}^{18}$. Niemniej pracownicy decydujący się na obniżenie wymiaru czasu pracy mają zagwarantowaną dwunastomiesięczną ochronę na gruncie art. $186^{8} \mathrm{kp}$. Ochrona taka przyznana została pracownikom od 2010 r. w wyniku zmian Kodeksu pracy dokonanych na gruncie Ustawy o zmianie ustawy Kodeks pracy z dnia 5 listopada 2009 r., która weszła w życie 6 stycznia 2010 r. ${ }^{19}$ Tak więc pracownik uprawniony, ale niekorzystający z urlopu wychowawczego, może domagać się obniżenia czasu pracy w celu sprawowania osobistej opieki nad dzieckiem. W tym miejscu wyjaśnienia wymaga rozumienie pojęcia sprawowanie osobistej opieki nad dzieckiem, które zostało wykształcone na gruncie art. $186 \mathrm{kp}$. Zgodnie przyjmuje się, że osobista opieka nie wyklucza korzystania z pomocy innych (osób, placówek, instytucji). Jako zaprzestania sprawowania osobistej opieki nad dzieckiem nie można traktować krótkotrwałej przerwy w sprawowaniu opieki, np. spowodowanej pobytem matki w szpitalu ${ }^{20}$. Również wszelkiego rodzaju okresowe przerwy w osobistej opiece nad dzieckiem, to znaczy naturalne i krótkie, jak i dłuższe spowodowane np. podróżami czy wypoczynkiem, nie zaważają nad sprawowaniem osobistej opieki nad dzieckiem. Ciężko bowiem oczekiwać, aby pracownik przez kilka lat nie mógł w ogóle opuścić swojego dziecka. Skoro celem urlopu wychowawczego jest stworzenie pracownikowi

${ }_{17}$ Zmiana terminu na złożenie wniosku z 7 dni na 21 dni nastąpiła w wyniku nowelizacji Kodeksu pracy ustawą z dnia 24 lipca 2015 r., która weszła w życie 2 stycznia 2016 r. Zakres dokumentów, które należy dołączyć do takiego wniosku, określa Rozporządzenie Ministra Rodziny, Pracy i Polityki Społecznej z 8 grudnia 2015 r. w sprawie wniosków dotyczących uprawnień pracowników związanych z rodzicielstwem oraz dokumentów dołączanych do takich wniosków, wydane zgodnie z dyspozycją art. 186 (8a) kp. W ciągu lat ustawodawca udoskonalał przedmiotową regulację, czyniąc stosowne doprecyzowanie w odniesieniu do formy wniosku o obniżenie wymiaru czasu, kształtując ostatecznie wymóg formy pisemnej wniosku.

${ }_{18}$ Przepis ten został uchylony w wyniku nowelizacji Kodeksu pracy ustawą z dnia 24 lipca 2015 r., która weszła w życie 2 stycznia 2016 r.

19 Dz. U., Nr 219, poz. 1704.

20 A. Martuszewicz, K. Piecyk, Urlopy pracownicze i inne zwolnienia od pracy, Warszawa 2010, passim. 
korzystnych warunków do sprawowania osobistej opieki nad dzieckiem w sytuacji trudności z połączeniem obowiązków opiekuńczych z obowiązkami zawodowymi, to tym bardziej cel ten realizowany jest właśnie przez możliwość obniżenia takiemu pracownikowi wymiaru czasu pracy. Zresztą ochrona, która w tym wypadku przysługuje pracownikowi, uznawana jest w doktrynie przedmiotu za szeroką ${ }^{21}$.

Od momentu złożenia przez pracownika wniosku o obniżenie wymiaru czasu pracy aż do dnia powrotu przez pracownika do nieobniżonego wymiaru czasu pracy pracodawca nie może rozwiązać ani wypowiedzieć umowy o pracę. Jeżeli więc pracownik złożył wniosek o obniżenie wymiaru czasu pracy już po dokonaniu przez pracodawcę czynności zmierzającej do rozwiązania umowy o pracę, umowa rozwiązuje się w terminie wynikającym z tej czynności (art. $186^{8} \$ 4 \mathrm{kp}$ ). Z tym że przepis nie rozróżnia czynności bezpośrednio zmierzających do rozwiązania stosunku pracy od czynności pośrednio zmierzających do tego skutku²2.

Możliwość obniżenia wymiaru czasu pracy przysługuje pracownikowi rodzicowi (opiekunowi), który pozostaje uprawniony do urlopu wychowawczego, niezależnie od płci. Tym samym mowa jest wyłącznie o pracownikach zatrudnionych przez co najmniej 6 miesięcy. Chodzi w tym przypadku o ogólny staż pracy obejmujący także okresy zatrudnienia u poprzednich pracodawców. Wymóg określający minimalny ogólny staż pracy, jakim powinien się legitymować zainteresowany rodzic (opiekun), pozostaje niezmienny mimo wielu nowelizacji ustawy. Wydaje się on adekwatny i dopasowany do celu tej instytucji i niewątpliwie pozostaje w zgodzie $\mathrm{z}$ wymogami prawa unijnego, które dopuszczają wprowadzenie rocznego stażu pracy jako przesłanki nabycia prawa do urlopu wychowawczego ${ }^{23}$. Należy podkreślić, że urlop wychowawczy - pośród innych regulacji mających na celu ochronę rodzicielstwa - jest jedynym przykładem, w którym staż pracy jest determinantą skorzystania z niego ${ }^{24}$. Możliwość skorzystania z urlopu wychowawczego jest uzależniona wyłącznie od dwóch elementów, jakimi są odpowiedni staż pracy oraz wiek dziecka, który w związku z ostatnimi nowelizacjami Kodeksu pracy z 2015 r. został wydłużony z 5. do 6. roku życia dziecka.

Należy przy tym zauważyć, że pracownik, składając wniosek o obniżenie wymiaru czasu pracy, nie ma możliwości zdecydowania o maksymalnym wymiarze czasu pracy w ramach zmniejszenia czasu pracy ${ }^{25}$. W literaturze przedmiotu można spotkać opinie, które dopuszczają możliwość dowolnego ustalenia przez strony stosunku pracy wymiaru czasu pracy pracownika uprawnionego do urlopu wychowawczego ${ }^{26}$. Zwolennicy

21 Zob. A. Węgrzyn, Żądanie obniżenia wymiaru czasu pracy a ochrona trwałości stosunku pracy, Monitor Prawa Pracy 2009, 12, s. 628.

22 Wyrok NSA z 16 lutego 2012 r., I OSK 1315/11, LEX, nr 1120587.

23 P. Walorska, Staż pracy, Warszawa 2014, passim.

24 Tamże.

25 P. Sołtys, Problematyka prawa obniżenia wymiaru etatu przez pracownika - rodzica wychowujacego dziecko, Studia z Zakresu Prawa Pracy i Polityki Społecznej 2014, s. 88.

26 A. Marek, Krótszy wymiar czasu pracy jako alternatywa urlopu wychowawczego, Służba Pracownicza 2004, 11, s. 11-14. 
tej koncepcji powołują się na brzmienie art. $8 \mathrm{kp}$, upatrując w nim uzasadnienia dla możliwości obniżenia wymiaru etatu o więcej niże połowę, pod warunkiem że takie rozwiązanie nie narusza zasad współżycia społecznego, nie przeczy interesom pracodawcy, a po stronie pracownika istnieje słuszny interes ${ }^{27}$. Pozostaję jednak w przekonaniu, iż takie obniżanie wymiaru czasu pracy kształtowanego wyłącznie wolą stron mogłoby doprowadzić do gradacji funkcji ochronnej tego przepisu. Poza tym zatarciu uległby podstawowy cel tej regulacji, który ma służyć pracownikowi rodzicowi łączącemu opiekę nad dzieckiem z pracą zawodową. W przypadku uznania, że regulacje ustawowe nie mają charakteru sztywnych norm i mogą podlegać dowolnej zmianie i być kształtowane wolą stron stosunku pracy, mogłoby dochodzić do marginalizowania funkcji ochronnej prawa pracy. Jeżeli pracownik wnioskuje o symboliczny etat, to w zasadzie można $\mathrm{z}$ dużym prawdopodobieństwem przypuszczać, że jego podstawowym celem jest w tym wypadku jedynie pozyskanie ochrony i być może nie ma w tym nic złego, ale wówczas wykonywanie pracy może czynić ją zupełnie nieracjonalną.

Aktualne brzemiennie przepisów Kodeksu pracy nie dookreśla liczby wniosków, które może złożyć pracownik uprawniony do urlopu wychowawczego. Za zasadne należy uznać poglądy doktryny ${ }^{28}$, w myśl których pracownik pozostaje uprawniony do złożenia więcej niż jednego wniosku o obniżenie wymiaru czasu pracy. A. Sobczyk ${ }^{29}$ słusznie zwraca uwagę, że w przypadku obniżenia wymiaru czasu pracy w kilku częściach w limicie 12-miesięcznej ochrony za każdym razem należy uwzględnić okres pomiędzy złożeniem danego wniosku a rozpoczęciem korzystania z uprawnienia. Nie istnieją również przeciwwskazania co do tego, aby pracownik naprzemiennie korzystał z urlopu wychowawczego i składał wniosek o obniżenie wymiaru czasu pracy, czyli tak naprawdę wykorzystywał to prawo w częściach. Poszczególne wnioski pracownika mogą przy tym wskazywać na różny wymiar czasu pracy, ale w granicach ustawowych. Przy takim częściowym wykorzystywaniu przez pracownika uprawnienia do obniżenia wymiaru czasu pracy okres rocznej ochrony podlega kumulacji. W literaturze przedmiotu prezentowane są - choć w mniejszości - poglądy, zgodnie z którymi okres rocznej ochrony nie może być dzielony na części, musi być okresem nieprzerwanym ${ }^{30}$. Biorąc pod uwagę czas trwania urlopu wychowawczego, może zdarzyć się tak, że pracownica, wykorzystując urlop wychowawczy, urodzi w trakcie jego trwania kolejne dziecko. Wówczas w zależności od jej decyzji może ona uprzednio skorzystać z obniżonego wymiaru czasu pracy i wynikającej z tego ochrony, a następnie przejść na kolejny urlop wychowawczy i ponownie obniżyć wymiar czasu pracy i ponownie uzyskać ochronę ${ }^{31}$.

$\mathrm{W}$ trakcie omawiania tematyki uprawnienia do obniżenia wymiaru czasu pracy konieczne jest zwrócenie uwagi również na to, że brzmienie obowiązujących przepisów

27 P. Sołtys, Problematyka prawa..., passim; A. Marek Krótszy wymiar..., s. 11-14. Por. także Postanowienie SN z 29.05. 2013, II PK 20/13, LEX, nr 1555442, nietezowane.

28 A. Sobczyk (red.), Kodeks pracy..., s. 793.

29 Tamże, s. 795.

${ }^{30}$ P. Sołtys, Problematyka prawa..., s. 92.

31 A. Sobczyk (red.), Kodeks pracy..., s. 794. 
nie wyjaśnia, czy w przypadku częściowego korzystania z tego uprawnienia przez oboje rodziców posiadają oni łączne prawo do ochrony przez dwanaście miesięcy, czy też każdemu z nich okres ochrony liczony będzie osobno. Szukając odpowiedzi na powyższe pytanie, można byłoby per analogiam posłużyć się rozwiązaniami przyjętymi przez ustawodawcę w art. $186 \$ 3^{1} \mathrm{kp}$, co oznaczałoby, że roczna ochrona przysługuje obojgu rodzicom łącznie przez okres jednego roku. Biorąc jednak pod uwagę brzmienie art. $189^{1} \mathrm{kp}$, skoro z ochrony przed zwolnieniem w związku z obniżeniem wymiaru czasu pracy korzystać może tylko jedno z rodziców lub opiekunów dziecka, to powinno ono przysługiwać niezależnie, osobno każdemu z rodziców lub opiekunów dziecka. Powyższe rozważania skłaniają do wniosków de lege ferenda, które miałyby uszczegółowić i doprecyzować kwestie dotyczące możliwości podziału prawa do obniżenia wymiaru czasu pracy oraz podziału tego uprawnienia pomiędzy oboje rodziców lub opiekunów dziecka.

Nie należy zapominać, że pracownik, który składa wniosek o obniżenie wymiaru czasu pracy, może jedynie wnioskować o obniżenie wymiaru czasu pracy, ale już nie o modyfikację rozkładu jego czasu pracy. Nie jest jednak wykluczone, aby pracodawca przystał na zaproponowane przez pracownika rodzica lub opiekuna zmiany i stworzył specjalnie dla niego indywidualny rozkład czasu pracy. Rozbieżności w literaturze przedmiotu dotyczą natomiast innej kwestii, a mianowicie możliwości cofnięcia wniosku przez pracownika o obniżenie wymiaru czasu pracy. W tym przypadku konieczne pozostaje posiłkowanie się regulacjami odnoszącymi się do urlopu wychowawczego. Zgodnie z brzmieniem nieobowiązującego już $\$ 5$ Rozporządzenia Ministra Pracy i Polityki Społecznej z dnia 19 września 2013 r. ${ }^{32}$ pracownik mógł wycofać wniosek o udzielenie urlopu wychowawczego nie później niż na 7 dni przed rozpoczęciem tego urlopu, składając pracodawcy pisemne oświadczenie w tej sprawie. Natomiast już po nadejściu terminu pracownik związany jest własnym wnioskiem i wówczas rezygnacja z urlopu wychowawczego może nastąpić w trybie uregulowanym w art. $186^{3} \mathrm{kp}$, a więc w każdym czasie - za zgodą pracodawcy lub po uprzednim zawiadomieniu pracodawcy najpóźniej na 30 dni przed zamierzonym podjęciem pracy. Ustalenie terminu, po którym pracownik związany jest własnym wnioskiem, leży w interesie pracodawcy, który mógł poczynić przygotowania w celu zastąpienia nieobecnego pracownika. Pracodawca może oczywiście wyrazić zgodę na wycofanie wniosku pracownika w każdym, dowolnym czasie. Obowiązujące aktualnie Rozporządzenie z dnia 8 grudnia 2015 r. $^{33}$ nie reguluje możliwości wycofania wniosku przez pracownika. Stąd też, mając na uwadze wykładnię

32 Rozporządzenie Ministra Pracy i Polityki Społecznej z dnia 19 września 2013 r. w sprawie szczegółowych warunków udzielania urlopu wychowawczego (Dz. U. 2013.1139).

${ }_{33}$ Rozporządzenie Ministra Rodziny, Pracy i Polityki Społecznej z dnia 8 grudnia 2015 w sprawie wniosków dotyczących uprawnień pracowników związanych z rodzicielstwem oraz dokumentów dołączanych do takich wniosków (Dz. U. 2015.2243). Zob. także E. Kumor-Jezierska, Komentarz do Rozporządzenia Ministra Rodziny, Pracy i Polityki Społecznej z dnia 8 grudnia 2015 r. w sprawie wniosków dotyczących uprawnień pracowników związanych $z$ rodzicielstwem oraz dokumentów dołaczanych do takich wniosków, w: Akty wykonawcze prawa pracy. Komentarz, K.W. Baran (red.), Warszawa 2016, s. 203. 
funkcjonalną, potrzeba zastosowania analogii do przepisów art. $186^{3} \mathrm{kp}$ staje się w pełni uzasadniona.

W świetle analizowanego przepisu przyjmuje się, że pracodawca pozostaje związany wnioskiem pracownika i co do zasady nie może odmówić jego realizacji. Ale czy obowiązek ten ma charakter bezwzględny? W literaturze przedmiotu zgodnie wyrażany jest pogląd, iż w przypadku wnioskowania przez pracownika o obniżenie wymiaru czasu pracy wyłącznie w celu pozyskania ochrony, a nie zaś w związku z koniecznością sprawowania osobistej opieki nad dzieckiem, istnieje możliwość odmowy ochrony prawnej takiemu pracownikowi ${ }^{34}$. Jeżeli więc pracownik $\mathrm{w}$ trakcie korzystania $\mathrm{z}$ obniżonego wymiaru czasu pracy wykonuje pracę lub prowadzi inną działalność zarobkową, to odmowa pracodawcy pozostaje $\mathrm{w}$ pełni uzasadniona. $\mathrm{W}$ takiej sytuacji możliwe jest również stwierdzenie wygaśnięcia tego prawa. Jeżeli przepisy regulują kwestię utraty prawa do urlopu wychowawczego - art. $186^{2} \$ 2 \mathrm{kp}$ - to przez analogię należy zastosować to rozwiązanie również do sytuacji obniżonego wymiaru czasu pracy.

\section{Pozorna ochrona stosunku pracy dla pracownika powracającego do pracy po wykorzystaniu urlopów związanych z rodzicielstwem}

Rozwiązanie umowy o pracę z pracownikiem uprawnionym do urlopu wychowawczego, który korzysta z obniżonego wymiaru czasu pracy, jest możliwe jedynie wówczas, gdy pracodawca ogłasza upadłość lub likwidację lub gdy zachodzą przyczyny uzasadniające rozwiązanie umowy o pracę bez wypowiedzenia $\mathrm{z}$ winy pracownika (art. $186^{8} \$ 2 \mathrm{kp}$ ).

Możliwość wypowiadania umów o pracę pracownikom korzystającym z obniżonego wymiaru czasu pracy powstaje w trakcie likwidacji, tak więc już sam fakt zarządzenia likwidacji przez pracodawcę może być podstawą do uzasadnienia wypowiedzenia takiemu pracownikowi umowy ${ }^{35}$. Proces likwidacji, podobnie jak upadłość, może trwać przez długi czas i brak jest uzasadnienia dla gorszego traktowania pracowników upadłego pracodawcy. Ponadto po zaprzestaniu działalności przez likwidowanego pracodawcę mogłoby zabraknąć środków finansowych na zaspokojenie roszczeń pracowniczych. Także w najnowszym orzecznictwie Sądu Najwyższego przyjmuje się, że skoro w Kodeksie pracy nie mówi się o „zlikwidowaniu” pracodawcy, lecz o jego „likwidacji”, to wystarcza samo zarządzenie likwidacji. Likwidacja ma dotyczyć pracodawcy jako całości, tak więc - zdaniem R. Sadlika - wypowiedzenia umowy o pracę nie uzasadnia likwidacja stanowiska pracy lub likwidacja części przedsiębiorstwa pracodawcy ${ }^{36}$. Należy zauważyć jednak, iż likwidacja stanowiska pracy może przecież pojawić się jako uzasadnienie przyczyny przy zwolnieniach grupowych, o czym więcej w dalszej części. Rozważając

34 A. Sobczyk (red.), Kodeks pracy..., s. 792.

35 Por. Wyrok SN z 10 września 1998 r., I PKN 310/98, OSNP 1999/19/614 SN w wyroku z 19 sierpnia 2004 r., I PK 489/03, OSNP 2005, nr 6, poz. 78.

${ }^{36}$ R. Sadlik, Wypowiedzenie umowy..., s. 20. 
tę kwestię, należy wskazać, że zgodnie z wyrokiem Sądu Najwyższego z dnia 23 maja 1997 r. ${ }^{37}$ likwidacja stanowiska pracy w ramach rzeczywistych zmian organizacyjnych, polegających na zmniejszeniu zatrudnienia, uzasadnia wypowiedzenie pracownikowi umowy o pracę. Likwidacja stanowiska pracy nie podlega ocenie sądu w płaszczyźnie zasadności i celowości działania pracodawcy. Sąd ocenia natomiast, czy jest ona rzeczywista, czy tylko pozorna oraz czy została wprowadzona zgodnie z prawem. Ma to praktyczne znaczenie zwłaszcza w przypadku złożonych i sformalizowanych struktur pracodawcy.

Drugą okolicznością uchylającą ochronę pracowników korzystających z obniżonego wymiaru czasu pracy jest ogłoszenie przez sąd upadłości pracodawcy. Mimo iż art. 186 (8) § 2 kp ogólnie stanowi o ogłoszeniu upadłości, należy mieć tu na względzie zarówno brzmienie art. 52 ustawy prawo upadłościowe ${ }^{38}$, zgodnie z którym data postanowienia sądu o ogłoszeniu upadłości jest datą ogłoszenia upadłości, jak i sytuacje obejmujące także otwarcie postępowania sanacyjnego - zgodnie z art. 300 ustawy prawo restrukturyzacyjne ${ }^{39}$. Na mocy tego przepisu otwarcie postępowania sanacyjnego wpływa na stosunki pracy i wywołuje w zakresie praw i obowiązków pracowników oraz pracodawców takie same skutki, jak ogłoszenie upadłości, przy czym uprawnienia syndyka wykonuje zarządca.

Na gruncie orzecznictwa Sądu Najwyższego wypracowany został pogląd, że skoro ustawa o zwolnieniach grupowych ${ }^{40}$ jest bezpośrednio stosowana do osób uprawnionych do skorzystania $z$ urlopów wychowawczych, to tym samym zastosowanie znajdzie do pracowników korzystających z obniżonego wymiaru czasu pracy. Tak więc pracodawca, który zatrudnia minimum 20 pracowników, może zastosować tryb zwolnień grupowych, o którym mowa w art. 5 ust. 1 ustawy, lub przeprowadzić zwolnienia w ramach wypowiedzenia indywidulanego zgodnie z art. 10 ust. 1 ustawy ${ }^{41}$. Wprawdzie Kodeks pracy nie wskazuje bezpośrednio na możliwość stosowania ww. ustawy do pracowników korzystających z obniżonego wymiaru czasu pracy, ale aktualna linia orzecznicza oparta na szczególnym charakterze owych przepisów dopuściła możliwość ich bezpośredniego stosowania $^{42}$. Sąd Najwyższy, uzasadniając swoje rozstrzygnięcie, przyznał, iż przepis art. $186^{1} \$ 1 \mathrm{kp}$ nie zawiera istniejącego zastrzeżenia co do możliwości rozwiązania umowy z przyczyn określonych w przepisach o szczególnych zasadach rozwiązywania z pracownikami stosunków pracy z przyczyn dotyczących pracodawcy, ale ustawa ta znosi niektóre zakazy rozwiązywania umów z pracownikami szczególnie chronionymi przepisami Kodeksu pracy i ustaw odrębnych. Stanowi ona lex specialis w stosunku do

37 I PKN 176/97, OSNAPiUS 1998, nr 9, poz. 263.

38 Ustawa z dnia 28 lutego 2003 r., prawo upadłościowe (Dz. U. 2016.2171 j.t.).

${ }^{39}$ Ustawa z dnia 15 maja 2015 r. prawo restrukturyzacyjne (Dz. U. 2016.1574 j.t.).

40 Ustawa z dnia 13 marca 2003 r. o szczególnych zasadach rozwiązania z pracownikami stosunków pracy z przyczyn niedotyczących pracowników (Dz. U. 2003 r., Nr 90, poz. 844).

${ }^{41}$ Wyrok SN z 12 maja 2011 r., II PK 6/11, LEX, nr 1171192, zob. także Ł. Pisarczyk, Zmniejszenie wymiaru czasu pracy-odpowiedź na potrzeby pracowników i kryzys przedsiębiorstwa, Praca i Zabezpieczenie Społeczne 2010, 6, s. 2 i n.

42 Zob. Wyrok SN z 29 czerwca 2005 r., II PK 332/04, OSNP 2006/5-6/83. 
tych przepisów i jej przepisy mają zastosowanie do rozwiązywania umów dokonanych w warunkach w niej określonych. Ponieważ regulacja zawarta w tej ustawie obejmuje wszystkich pracowników z wyjątkami w niej wymienionymi (art. 11), wprowadzenie do Kodeksu pracy przepisu dotyczącego szczególnej ochrony pracowników korzystających z urlopu wychowawczego nie wymagało dodatkowego zastrzeżenia odwołującego się do ustawy. Stoję na stanowisku, że przejęta przez Sąd Najwyższy wykładnia przepisów doprowadziła do znacznego osłabienia pozycji pracownika powracającego do pracy po wykorzystaniu urlopów o charakterze rodzicielskim. Szczególnie jeżeli chodzi o możliwość zastosowania art. 10 ust. 1 i 2 ustawy z 13 marca 2003 r. Na gruncie tych regulacji możliwość wypowiedzenia umowy nie stanowi w zasadzie dla pracodawcy większego problemu, a często dyktowana jest sytuacją związaną z samym pracownikiem, który odchodząc z pracy na czas sprawowania osobistej opieki nad dzieckiem, niejako zmusza pracodawcę to przesunięć stanowiskowych, kadrowych.

Odrębną od art. $186^{6} \mathrm{kp}$ regulację stanowi również art. 241 (13) $\$ 2$ kp, który wyłącza ochronę stosunku pracy w razie zmian prawa zakładowego (układu zbiorowego pracy lub regulaminu wynagradzania) na mniej korzystne. Pracodawca ma prawo do zmiany prawa płacowego, która to zmiana ma charakter powszechny i podmiotowo odnosi się do wszystkich pracowników objętych tą zmianą, ze względu na generalny (normatywny) charakter norm tego prawa.

Poza wymienionymi w art. $186^{8} \$ 1 \mathrm{kp}$ przypadkami nieakceptowalne jest kreowanie nowych, nieznanych ustawie okoliczności, w których pracodawca ma prawo zakończyć umowę z pracownikiem uprawnionym do urlopu wychowawczego, a występującym o obniżenie wymiaru czasu pracy ${ }^{43}$.

\section{Podsumowanie}

Analizując przepisy dotyczące sytuacji prawnej pracownika powracającego do pracy po wykorzystaniu urlopów związanych z rodzicielstwem, można dojść do przekonania, iż na ich gruncie powszechna ochrona trwałości stosunku pracy nie jest realizowana w sposób zadowalający. Przyjęty w Polsce oraz Unii Europejskiej ustrój społecznej gospodarki rynkowej przesądza o tym, że w polityce społecznej państwo musi uwzględniać interesy zarówno pracodawców, w tym ich prawo do prowadzenia wolnej działalności gospodarczej, jak i pracowników, z ich prawem do ochrony przed arbitralnym zwolnieniem z pracy ${ }^{44}$. Mając powyższe na względzie, konieczne wydaje się, aby móc realizować cel gwarancji zatrudnienia dla pracowników rodziców (opiekunów), stworzenie odpowiedniego systemu wsparcia poprzez dofinansowanie pracodawcom miejsc pracy dla tej grupy zatrudnionych. Konstrukcyjnie przepisy Kodeksu pracy nie tworzą większych problemów interpretacyjnych, choć momentami wymagają zmian uszczegóławiających istniejące

\footnotetext{
${ }^{43}$ Wyrok SN z 8 grudnia 2016, II PK 264/15, LEX, nr 2188629.

${ }^{44}$ A. Rycak, Powszechna ochrona trwałości stosunku pracy, Warszawa 2013, s. 289.
} 
rozwiązania. Pracownik rodzic (opiekun) powracający do pracy po przerwie związanej z opieką nad dzieckiem powinien mieć silniejsze oparcie na gruncie ustawy. Przypadki umożliwiające zakończenie stosunku pracy z pracownikiem uprawnionym do urlopu wychowawczego powinny być interpretowane możliwie wąsko.

W każdej dyskusji o uprawnieniach związanych z rodzicielstwem należy pamiętać o tym, aby nie podchodzić do zagadnienia rodziny wyłącznie w kategoriach ekonomicznych ${ }^{45}$. Nie ulega wątpliwości, że podstawowym celem polityki prorodzinnej jest przede wszystkim dobro dziecka jako wartość sama w sobie ${ }^{46}$. Z tym że cel ten, mimo iż najistotniejszy, nie powinien przysłaniać innych, mniejszych, ale równie ważnych wartości, a mianowicie wzmacniania sytuacji prawnej pracowników (rodziców, opiekunów) powracających na rynek pracy po przerwie wywołanej urlopem o charakterze rodzicielskim.

\section{Bibliografia}

Kumor-Jezierska E., Komentarz do Rozporzadzenia Ministra Rodziny, Pracy i Polityki Społecznej $z$ dnia 8 grudnia 2015 r. w sprawie wniosków dotyczących uprawnień pracowników związanych $z$ rodzicielstwem oraz dokumentów dołączanych do takich wniosków, w: Akty wykonawcze prawa pracy. Komentarz, K.W. Baran (red.), Warszawa 2016.

Latos-Miłkowska M., Przemiany stosunku pracy związane z rodzicielstwem, w: Współczesne problemy prawa pracy i ubezpieczeń społecznych, L. Florek, Ł. Pisarczyk (red.), XVIII Zjazd Katedr i Zakładów Prawa Pracy i Ubezpieczeń Społecznych, Warszawa, 26-28 maja 2011.

Marek A., Krótszy wymiar czasu pracy jako alternatywa urlopu wychowawczego, Służba Pracownicza 2004, 11.

Martuszewicz A., Piecyk K., Urlopy pracownicze i inne zwolnienia od pracy, Warszawa 2010.

Pisarczyk Ł., Zmniejszenie wymiaru czasu pracy - odpowiedź na potrzeby pracowników i kryzys przedsiębiorstwa, Praca i Zabezpieczenie Społeczne 2010, 6.

Rycak A., Powszechna ochrona trwałości stosunku pracy, Warszawa 2013.

Sadlik R., Wypowiedzenie umowy pracownikowi z obniżonym wymiarem czasu pracy, Służba Pracownicza 2013, 7.

Sobczyk A. (red.), Kodeks pracy. Komentarz, wyd. 2, Warszawa 2015.

Sobczyk A., Prawo dziecka do opieki rodziców jako uzasadnienie dla urlopu i zasitku macierzyńskiego, Praca i Zabezpieczenie Społeczne 2015, 9.

Sołtys P., Problematyka prawa obniżenia wymiary etatu przez pracownika - rodzica wychowujacego dziecko, Studia z Zakresu Prawa Pracy i Polityki Społecznej 2014.

Torbus U., Zmiany w zakresie uprawnień rodzicielskich ułatwiających łączenie obowiązków zawodowych zopieka nad dzieckiem, w: Uprawnienia pracowników związane z rodzicielstwem

${ }^{45}$ U. Torbus, Zmiany w zakresie uprawnień..., s. 225.

${ }^{46}$ Por. A. Sobczyk, Prawo dziecka do opieki rodziców jako uzasadnienie dla urlopu i zasiłku macierzyńskiego, Praca i Zabezpieczenie Społeczne 2015, 9, s. 11 i n. 
w świetle przepisów prawa pracy i ubezpieczeń społecznych, J. Czerniak-Swędzioł (red.), Warszawa 2016.

Walorska P., Staż pracy, Warszawa 2014.

Węgrzyn A., Żądanie obniżenia wymiaru czasu pracy a ochrona trwałości stosunku pracy, Monitor Prawa Pracy 2009, 12.

Włodarczyk M., Komentarz do art. $183^{2}$ kp, w: Kodeks pracy. Komentarz, K.W. Baran (red.), Warszawa 2015.

Wujczyk M., Wypowiedzenie warunków pracy lub płacy w umownym stosunku pracy, Warszawa 2015.

Wyrok SN z 1 października 1984 r., I PRN 129/84, OSNCP 1985, nr 7 poz. 93.

Uchwały SN z 30 grudnia 1985 r., III PZP 50/85, OSNCP 1986, nr 7-8, poz. 118.

Wyrok SN z 23 maja 1997 r., I PKN 176/97, OSNAPiUS 1998, nr 9, poz. 263.

Wyrok SN z 10 września 1998 r., I PKN 310/98, OSNP 1999/19/614.

Wyrok SN z 19 sierpnia 2004 r., I PK 489/03, OSNP 2005, nr 6, poz. 78.

Wyrok SN z 29 czerwca 2005 r., II PK 332/04, OSNP 2006/5-6/83.

Wyrok SN z dnia 29 stycznia 2008 r. sygn. akt II PK 143/07.

Wyrok SN z 12 maja 2011 r., II PK 6/11, LEX, nr 1171192.

Wyrok NSA z 16 lutego 2012 r., I OSK 1315/11, LEX, nr 1120587.

Wyrok SN z 8 grudnia 2016, II PK 264/15, LEX, nr 2188629. 